Sains Malaysiana 47(9)(2018): 1961-1967

http://dx.doi.org/10.17576/jsm-2018-4709-03

\title{
Termite Associated to Oil Palm Stands in Three Types of Soils in Ladang Endau Rompin, Pahang, Malaysia
}

(Sekutuan Anai-anai dengan Pokok Sawit dalam Tiga Jenis Tanah di Ladang Endau Rompin, Pahang, Malaysia)

\author{
NUR-ATIQAH JALALUDIN, FASZLY RAHIM \& SALMAH YAAKOP*
}

\begin{abstract}
Termites are found in various habitats, particularly diverse communities occurring in tropical forest and peatlands. Termites are beneficial insects, which function as soil engineers, improving the soil quality. However, in peatlands converted to commercial oil palm plantations, they are considered as pests. There is lack of studies on termite communities in converted peatlands in Peninsular Malaysia. Thus, this study investigated termite species associated with oil palm stands in three soil types (clay, shallow peat and deep peat) in Endau Rompin Plantation. The stand scouting method was used to record the numbers and types of termites associated with palm trees in the individual stands on different soil types. A total of 29 termite species associated with the palm stands were identified morphologically. All the species belonged to the families Rhinotermitidae and Termitidae. Twenty-three of the 29 species were found in the shallow peat, 16 in clay soil and 15 in deep peat. The community structure was synthesized by two-way cluster analysis with Sorensen (Bray Curtis) distance measure. Five termite groups associated with two soil types (clay soil and shallow/deep peat) were generated. Moisture levels and organic content were likely to determine the presence of soil feeders identified in the presence study. This study provides information on the status of termite species in oil palm plantation areas. Such information may be useful in future planning strategies by the plantation management.
\end{abstract}

Keywords: Oil palm; peatland; Peninsular Malaysia; termite census; termite diversity

ABSTRAK

Anai-anai banyak direkodkan di pelbagai habitat terutamanya di hutan tropika dan tanah gambut. Anai-anai adalah serangga yang penting sebagai jurutera ekosistem yang berfungsi dalam meningkatkan kualiti tanah. Walau bagaimanapun, anai-anai dianggap sebagai perosak di kawasan tanah gambut yang ditukar status kepada tanah komersial. Sehingga kini, kurang kajian mengenai komuniti anai-anai di tanah gambut tersebut di Semenanjung Malaysia. Oleh itu, kajian ini dijalankan untuk mengkaji anai-anai yang bersekutu dengan pokok sawit di tiga jenis tanah di Ladang Endau Rompin. Kaedah stand scouting digunakan untuk merekod jumlah kehadiran dan jenis anai-anai yang bersekutu dengan setiap pokok sawit di jenis tanah yang berbeza. Sejumlah 29 spesies anai-anai telah direkodkan dan telah dikenal pasti dengan ciri-ciri morfologi. Kesemua spesies yang direkodkan adalah daripada famili Rhinotermitidae dan Termitidae. Dua puluh tiga daripada 29 spesies direkodkan di tanah jenis tanah gambut cetek, 16 spesies di tanah liat dan 15 spesies direkodkan di tanah gambut dalam. Struktur komuniti anai-anai ini telah dihasilkan dengan pengukuran jarak Sorensen (Bray-Curtis). Lima kumpulan anai-anai yang bersekutu dengan dua jenis tanah (tanah liat dan tanah gambut dalam/ cetek) telah dihasilkan. Tahap kelembapan dan kandungan organik tanah dilihat dapat menentukan kehadiran anai-anai pemakan tanah dalam kajian ini. Kajian ini dapat memberikan status kehadiran spesies anai-anai di ladang sawit yang berguna untuk perancangan strategi bagi pihak pengurusan ladang.

Kata kunci: Kelapa sawit; kepelbagaian anai-anai; Semenanjung Malaysia; sensus anai-anai; tanah gambut

\section{INTRODUCTION}

Termites are found in various habitats from subtropical to tropical region but are most abundant in the tropical forest (Jouquet et al.2011). Termites are beneficial insects in the ecosystem, where they function as soil engineers which their activities creating a favourable environment for other organisms. Termites colonies decompose dead materials, cycle nutrients, fix nitrogen, and contribute to carbon fluxes cycle in soil (Fox-Dobbs et al. 2010; Jouquet et al. 2011). They improve soil quality generally via various behaviours, such as soil feeding, tunneling and mound building (Evans et al. 2011; Jouquet et al. 2004). In lands converted for commercial uses, termites that feed on dead logs and living plants are considered pests (Harris 1969; Kirton \& Wong 2001). The activities of termites pose a threat in large-scale plantation, such as rubber and oil palm (Lee 2002).

At present, Malaysia and Indonesia are the two leading producers of oil palm (FAO 2010). The diversity of termite species in oil palm plantations has been the subject of little research in Malaysia and elsewhere (Foster et al. 2011). In previous research, 75 termite species were recorded in Peninsular Malaysia (Tho 1992) and 103 termite species 
were recorded in Sabah (Thapa 1981). Some recent studies on termite diversity in peatlands in Sarawak, Malaysia have been reported by Bong et al. (2012), Kon et al. (2012) and Vaessen et al. (2011). Vaessen et al. (2011) identified 20 species at four sites in Sarawak in their study of termite activity in converted peatlands. Bong et al. (2012) reported that wood feeders are the most abundant termite species among 13 termite species recorded in Sarawak. Kon et al. (2012) also reported that wood-feeding termites predominated in oil palm stands of different ages. In Sabah, most studies of the diversity of termite species have been done in logged forests (Donovan et al. 2007; Eggleton et al. 1999).

Termite distribution patterns vary regionally, and various environmental factors, such as vegetation type, habitat disturbance and habitat fragmentation influence local patterns (Dawes 2010; De Souza et al. 1994; Jones \& Eggleton 2000; Jones et al. 2003). As termites are sensitive to habitat disturbance, with resulting decreases in diversity, their distribution patterns can be used to shed light on the impact of habitat conversion (e.g. conversion of tropical forest to plantations).

Most studies of termite diversity in Malaysia have been conducted in peat swamp converted forest in Sarawak (Bong et al. 2012; Kon et al. 2012; Vaessen et al. 2011). There have been no studies of termite diversity in peat swamps converted to oil palm plantations in different types of soils. Therefore, this study aimed to collect fundamental data on termite species associated with oil palm stands on a converted peatland site in Endau Rompin Plantation, Pahang. The results should prove useful for oil palm management and conservation strategies in the plantation area.

\section{MATERIALS AND METHODS}

\section{SAMPLING SITE}

Termite sampling was conducted in Endau Rompin Estate, Pahang ( $\left.2^{\circ} 36^{\prime} \mathrm{N}, 103^{\circ} 34^{\prime} \mathrm{E}\right)$, a peatland converted oil palm plantation. The study site has yet to apply chemical spraying and still evaluating management strategies. The plantation consists of alternating rows of palm trees, harvesting paths, field drains, and stacking rows in a 16ha field block. Blocks were selected randomly, with each block consisting of maximum of 30 palm stands in 80 palm rows. Three different types of soil were identified in the plantation: clay soil, shallow peat and deep peat. The presence of termite species in stands aged between 8 and 17 years in the study plots (approximately 144 ha) of each soil type in the plantation area was then assessed (Figure 1).

\section{SAMPLING TYPE}

The stand scouting method was applied, with each palm tree searched from ground level up to a 2-m level to detect the presence of termites. The survey of about 19,000 palm trees in nine blocks focus on searching of the presence of termite trail and mound on palm trees (for arboreal and epigeal mounds) including the fronds. Each tree took about $30 \mathrm{~s}$ to one minute of survey including the time for collecting samples and data marking. The scouting started from the first row of palm trees adjacent to the road and continued through the block boundary at the end of the rows of 30 palm trees. Each four rows of palm trees divided by field drain and four trained persons worked side by side and continuously scouting for $30 \mathrm{~min}$ for each

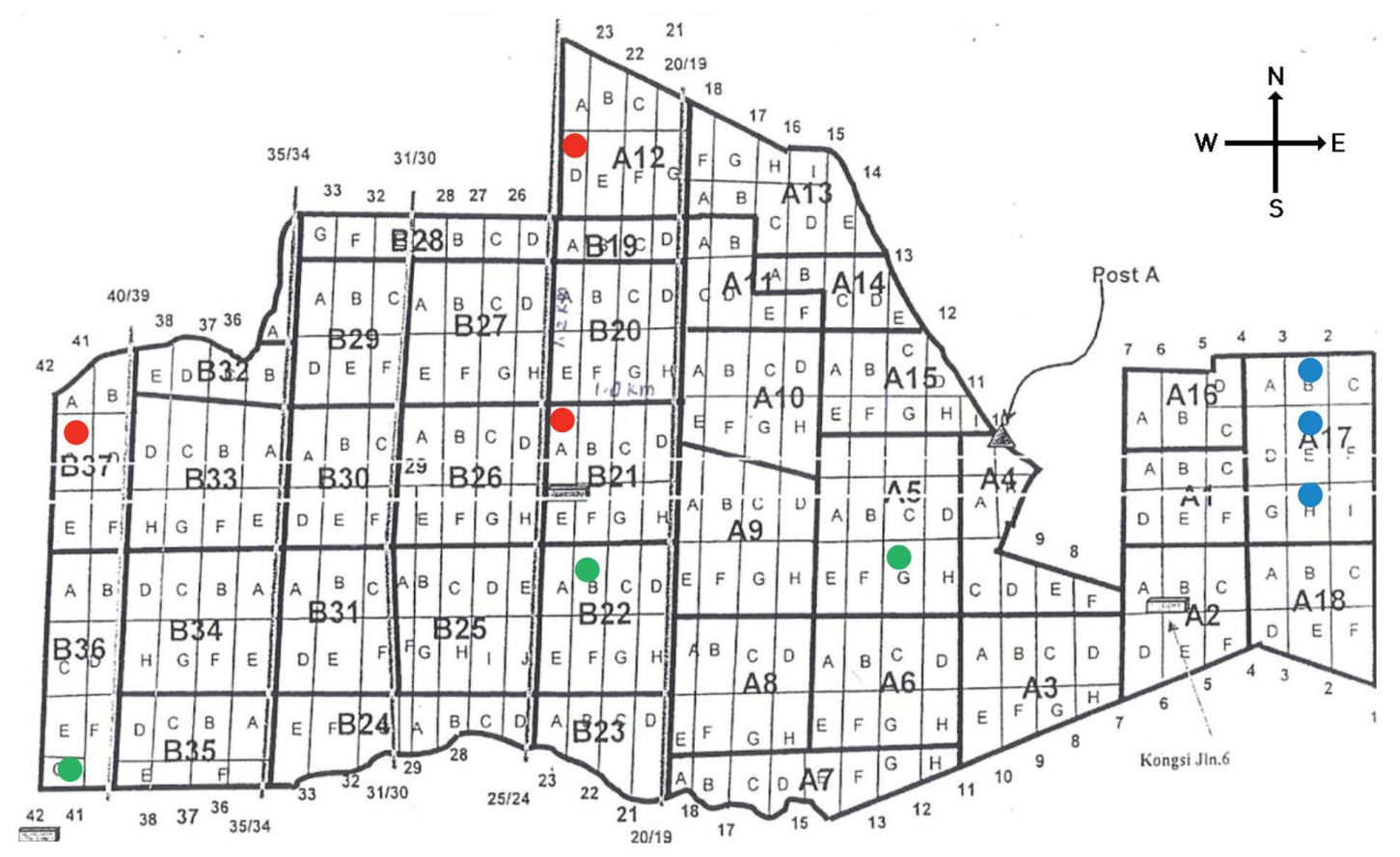

FIGURE 1. Map of Endau Rompin Plantation. A17B, A17E and A17H represent clay soil (blue),

B36G, B22B and A5G represent shallow peat (green) and A12D, B21A and B37C represent deep peat (red) 
row. The presence of termite in the trail was marked on a census sheet (Figure 2), which was designed according to the arrangement of the oil palm stands in the 16-ha field block area. Termite samples were collected and labelled according to soil type, field block, and grid of palm tree. The samples were brought back to the laboratory and preserved in $70 \%$ alcohol.

\section{SPECIES IDENTIFICATION}

Using a dissecting microscope, the termite species were identified based on morphological characteristics up to species level, according to the methods of Syaukani (2010), Thapa (1981) and Tho (1992). The characteristics of the termites, especially those of the head (length and width), number of antennal segments and mandibles, were recorded. All the records were made in $\mathrm{mm}$. Three individuals from each termite colony were used to identify the species. The termites were further categorized into feeding and nesting group according to the known feeding group classified in Donovan et al. (2001) and Rahman and Tawatao (2003), which then Donovan et al. (2001) further grouping the termite into four groups by gut content analysis.

\section{DATA ANALYSIS}

The identified termite species and their association with the different types of soils were analyzed by two-way cluster analysis of the termite species data, using the Sorensen (Bray-Curtis) distance measure. A dendrogram was generated based on the similarity of present-absent termite species in the three types of soil. A flexible beta value of -0.25 was selected to measure the difference in termite community structure to form different groups. To identify similar groups of termites associated with the different soil types, the preferred percentages of information remaining were generated by PC-ORD software (McCune \& Mefford 2011) to calculate the percentage of similarity on soil types and termite community group.

\section{RESULTS AND DISCUSSION}

\section{SPECIES COMPOSITION}

A total of 29 termite species were associated with the palm stands in Endau Rompin Plantation. These termite species consisted of three genera under family Rhinotermitidae
(Schedorhinotermes, Parrhinotermes and Coptotermes) and seven genera in the family Termitidae (Amitermes, Globitermes, Microcerotermes, Termes, Pericapritermes, Nasutitermes and Bulbitermes). Of the 10 genera identified, Nasutitermes spp. were the most common with seven species followed by Schedorhinotermes spp., Pericapritermes spp. and Coptotermes spp. with four species. Globitermes sp., Termes sp. and Amitermes sp. were the least common, with just one species each recorded (Table 1).

With regard to the soil type, the highest numbers of termite species were recorded in shallow peat $(n=23)$. Sixteen and 15 species were recorded in clay soil and deep peat, respectively. Four species were found only in association with the clay soil: Schedorhinotermes sp. A, Nasutitermes atripennis, Microcerotermes dubius and $M$. crassus. Five species were present only in shallow peat: Parrhinotermes pygmaeus, Pericapritermes buitenzorgi, P. speciosus, P. semarangi and Microcerotermes havilandi. $N$. longinasoides was present only in deep peat. Six species present in all three types of soils: $N$. havilandi, $N$. matangensis, $N$. roboratus, $N$. sp. A., S. medioobscurus and Globitermes globosus (Table 2).

The present study identified 29 species, 25 of the species recorded on palm at peat soil blocks which was considerably higher than that reported in previous studies in peatland converted oil palm area in Sarawak, Malaysia in which 13 (Bong et al. 2012), 18 (Kon et al. 2012) and 20 (Vaessen et al. 2011) were recorded. Based on the present findings, oil palm plantations in Peninsular Malaysia harbor higher numbers of termite species than similar oil palm plantations in Sabah and Sarawak, as Borneo harbor more species that are less susceptible to environmental changes (Hassall et al. 2006; Jones et al. 2003). A similar trend in termite species number was found in primary forest in Belum Forest, Perak in Peninsular Malaysia, with higher numbers (40 species) compared to primary forest in Lipad Virgin Jungle in Sabah, Borneo (29 species) (Hanis et al. 2014; Keng \& Rahman 2012).

The termite diversity in Endau Rompin plantation was slightly lower compare to termite diversity in primary forest (39 termite species) but higher when compared to that in logged forest (14 species) (Donovan et al. 2007). Other studies reported similar findings, with slightly lower termite diversity in oil palm plantations and logged forests compared to old growth forests (Keng \& Rahman 2012; Luke et al. 2014). However, a sampling study in

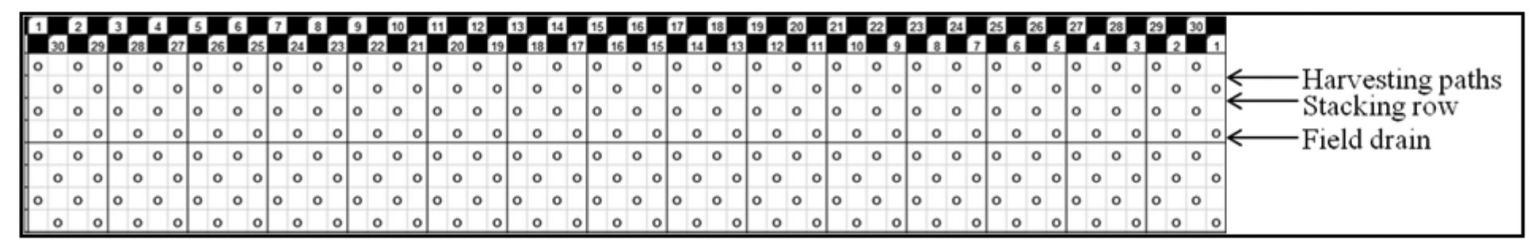

FIGURE 2. Census sheet consisting of alternating rows of palm trees (the circles arrangement), harvesting paths, stacking rows and field drains. Figure shows 30 palm stands in eight palm rows 
TABLE 1. List of termite species collected that associated with palm stand in Endau Rompin Plantation marked with the presence on three different types of soils

\begin{tabular}{|c|c|c|c|c|c|c|}
\hline No. & Termite species & $\begin{array}{c}\text { Feeding } \\
\text { Group }\end{array}$ & $\begin{array}{l}\text { Nesting } \\
\text { Group }\end{array}$ & Clay & $\begin{array}{c}\text { Shallow } \\
\text { peat }\end{array}$ & Deap peat \\
\hline 1 & Nasutitermes havilandi & $\mathrm{w}$ & $\mathrm{a}$ & & & \\
\hline 2 & Nasutitermes matangensis & $\mathrm{w}$ & $\mathrm{a}$ & & & \\
\hline 3 & Nasutitermes longinasoides & $\mathrm{w}$ & $\mathrm{a}$ & & & \\
\hline 4 & Nasutitermes roboratus & $\mathrm{w}$ & $\mathrm{a}$ & & & \\
\hline 5 & Nasutitermes sp. A & w & $\mathrm{a}$ & & & \\
\hline 6 & Nasutitermes neopusillus & w & $\mathrm{a}$ & & & \\
\hline 7 & Nasutitermes atripennis & w & $\mathrm{a}$ & & & \\
\hline 8 & Nasutitermes proatripennis & w & $\mathrm{a}$ & & & \\
\hline 9 & Schedorhinotermes malaccensi & $\mathrm{w}$ & $\mathrm{w}$ & & & \\
\hline 10 & Schedorhinotermes medioobscurus & w & $\mathrm{w}$ & & & \\
\hline 11 & Schedorhinotermes sp. A & $\mathrm{w}$ & w & & & \\
\hline 12 & Parrhinotermes aequalis & w & w & & & \\
\hline 13 & Parrhinotermes pygmaeus & $\mathrm{w}$ & $\mathrm{w}$ & & & \\
\hline 14 & Pericapritermes buitenzorgi & s & $\mathrm{h}$ & & & \\
\hline 15 & Pericapritermes mohri & s & $\mathrm{h}$ & & & \\
\hline 16 & Pericapritermes speciosus & $\mathrm{s}$ & $\mathrm{h}$ & & & \\
\hline 17 & Pericapritermes semarangi & $\mathrm{s}$ & $\mathrm{h}$ & & & \\
\hline 18 & Coptotermes curvignathus & w & $\mathrm{w}$ & & & \\
\hline 19 & Coptotermes kalshoveni & w & w & & & \\
\hline 20 & Coptotermes sepangensis & w & $\mathrm{w}$ & & & \\
\hline 21 & Coptotermes gestroi & $\mathrm{w}$ & $\mathrm{w}$ & & & \\
\hline 22 & Globitermes globosus & w & $\mathrm{h}$ & & & \\
\hline 23 & Termes rostratus & $\mathrm{w} / \mathrm{s}$ & $\mathrm{w}$ & & & \\
\hline 24 & Amitermes dentatus & $\mathrm{w} / \mathrm{s}$ & $\mathrm{i}$ & & & \\
\hline 25 & Bulbitermes contrictiformis & w & $\mathrm{a}$ & & & \\
\hline 26 & Bulbitermes neopusillus & w & $\mathrm{a}$ & & & \\
\hline 27 & Microcerotermes havilandi & $\mathrm{w}$ & $\mathrm{w}$ & & & \\
\hline 28 & Microcerotermes dubius & w & $\mathrm{a}$ & & & \\
\hline 29 & Mictrocerotermes crassus & $\mathrm{w}$ & $\mathrm{a}$ & & & \\
\hline \multicolumn{4}{|c|}{ Percentage of species (\%) } & 55.17 & 79.31 & 51.72 \\
\hline
\end{tabular}

Feeding Group: wood feeder $=\mathrm{w}$; soil feeder $=\mathrm{s}$; intermediate wood and soil feeder $=\mathrm{w} / \mathrm{s}$. Nesting Group: wood nester $=\mathrm{w} ;$ hypogeal nester or subterranean $=\mathrm{h}$; arboreal nester $=\mathrm{a}$; inquiline nester $=\mathrm{i}$

TABLE 2. Number of overlapping termite species in clay, shallow peat and deep peat

\begin{tabular}{lccc}
\hline & Clay & Shallow peat & Deep peat \\
\hline Clay & - & 11 & 7 \\
Shallow peat & 11 & - & 13 \\
Deep peat & 7 & 13 & - \\
\hline
\end{tabular}

Belum Forest, Perak identified 40 species, which was higher than that found in the present study in Endau Rompin Plantation (Hanis et al. 2014). As reported elsewhere, habitat disturbance and changes in habitat suitability for termites and other soil invertebrates have led to dramatic reductions in termite species abundance in oil palm converted lands and logged forests (Donovan et al. 2007; Jones et al. 2003). The latter, changes in habitat 
suitability may affect the quality and suitability of soil for other organisms.

Most of the species present in plantations are wood feeders rather than soil feeders (Rahman \& Tawatao 2003). Wood feeders are also more common than soil feeders in logged forests (Bourguignon et al. 2011; Hemachandra et al. 2010). Wood feeders are found in the presence of dead wood and wood debris. A high amount of organic matter from decaying wood explains the predominance of soil feeders in primary forests (Jones et al. 2003).

\section{CLUSTERING ANALYSIS BASED ON SOIL TYPES}

The two-way cluster analysis and Sorensen (Bray-Curtis) distance measure (McCune \& Mefford 2011) identified five groups of termite assemblages. The assemblages of termite in clay soil were significantly different from those in shallow/deep peat (Figure 3). Group 1, which consisted of $N$. havilandi, $N$. matangensis, $N$. roboratus, $N$. sp. A., S. medioobscurus, G. globosus and B. neopusillus were all wood feeders and mostly arboreal nesters. Group 2 comprised N. longinasoides, S. malaccensis, P. aequalis, $C$. curvignathus, C. kalshoveni, C. sepangensis, C.gestroi and A. dentatus. These were all wood feeders and mostly wood nesters. Group 3 consisted of P. pygmaeus, P. buitenzorgi. P. speciosus, P. semarangi and M. havilandi and they were wood and soil feeders. N. neopusillus, $N$. proatripennis, $P$. mohri, T. rostratus and B. constrictiformis were mostly wood feeders and were found only in clay and deep peat, made up Group 4. Group 5 comprised $S$. sp.A, N. atripennis, M.dubius and M. crassus and they were all wood feeders and mostly arboreal nesters. The groups were classified according to their presence in the three types of soils and $90 \%$ similarity in termite community groups (Figure 3 ).

Group 1 termites were found in all the soil types. They were all wood feeders and most were arboreal, subterranean, or epigeal nesters, as reported elsewhere (Rahman \& Tawatao 2003). Given the varied nesting habits of these species, soil condition alone does not determine their presence. The Group 2 termites were also wood feeders, but were present only in the peat soil area. Group 3 consisted mainly of soil feeders, and they were present only in the shallow peat soil area. Termite species classified in Group 2 and 3 are peat soil species which these species have no record in clay soil area. According to Kon et al. (2012), the presence of these types of feeders may be explained by the high organic content in shallow peat. Additionally, canopy cover was shown to determine the abundance of termites in a given area (Dibog et al. 1999). An open canopy cover affects both temperature and moisture levels. The latter may explain the absence of soil feeders present in the clay soil and deep peat in the present study. Group 4 termites were present in clay soil and shallow peat. T. rostratus which is an intermediate feeder, was found in this group. Group 5 termite species were present only in clay soil areas, and they were all are wood feeders and wood nesters or arboreal. These termites feed on wood and live in feeding galleries (Rahman \& Tawatao 2003).

The unique standardized field designs of the plots (the palms arrangement in each plot) in Endau Rompin Plantation make the site suitable for termite census studies. As none of termite species monitoring studies on peatland were conducted in Peninsular Malaysia, it is important to study the effect of land conversion, as termites are sensitive to disturbance (Dawes 2010). According to previous studies, $13.3 \%$ of oil palm grown in Malaysia is cultivated on peat soil (Kon et al. 2012; Omar et al.2010). Although oil palm plantations are cultivated on peatland in Malaysia and worldwide, little is known about the impact of these plantations on the biodiversity

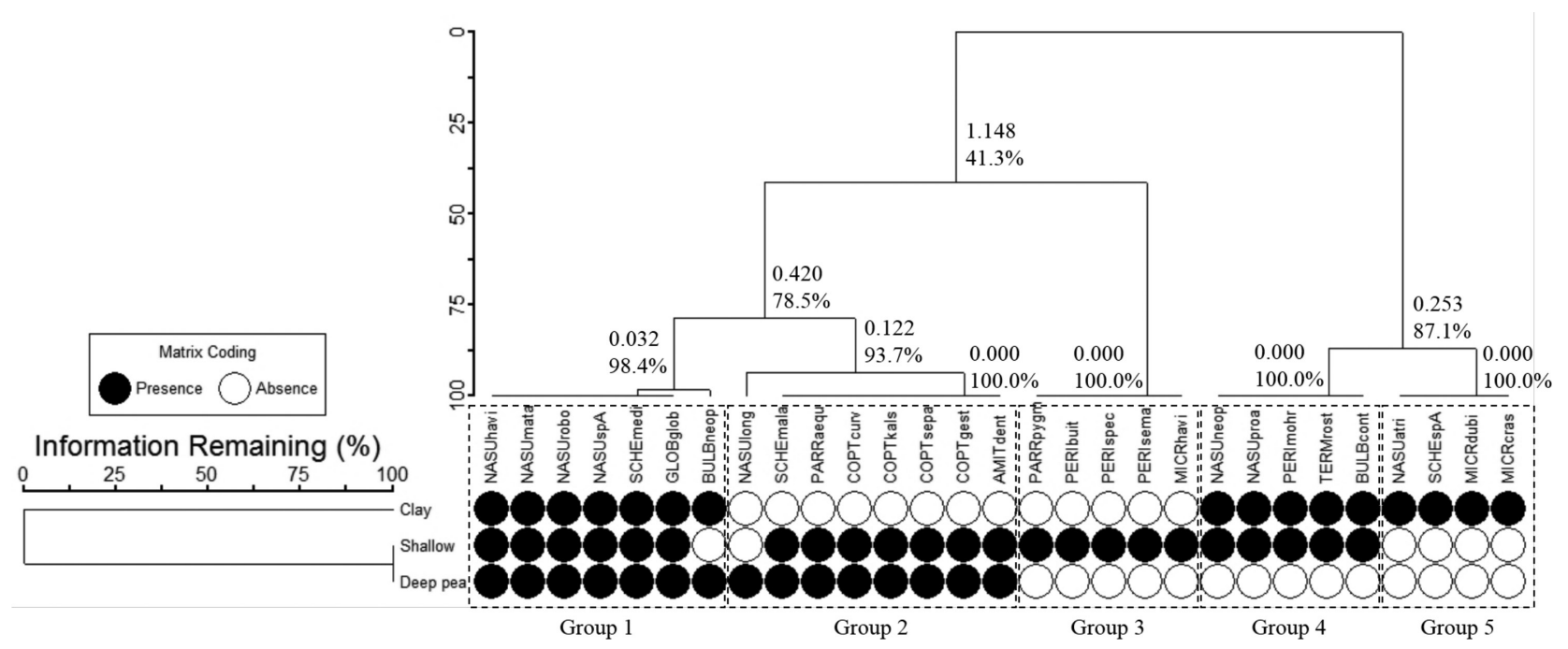

FIGURE 3. Dendrogram of clustering of termite species based on present-absent data generated by PC-ORD analysis of distance measure by Sorensen. Five groups of termite community were generated and two group of soil generated with $100 \%$ similarity in both shallow and peat soil (Black=presence; white=absence) 
of termites (Turner et al. 2011). The present study can aid understanding of termite occurrence in peatland converted oil palm plantations.

The highest numbers of termite species were recorded in the shallow peat soil and the number is slightly higher compared to deep peat and clay soil. Termites are known to favour a soil type with a high moisture-holding capacity and high organic matter content (Lim \& Silek 2001). Clay holds less moisture and organic matter than peat (Lim $\&$ Silek 2001). In a previous study, the composition of clay was the main factor responsible for low numbers of termites in the clay soil area (Lim \& Silek 2001). Four of the termite species were found specific to clay soil. These four species are wood feeders mostly arboreal (Donovan et al. 2001; Rahman \& Tawatao 2003). In the current study, five species were present only in shallow peat. These were wood feeders/wood nesters and soil feeders/subterranean nesters. $N$. longinasoides, a wood feeder and arboreal nester, was present only in deep peat. The dominant species, which was found in all three types of soils, were all wood feeders, in common with the findings of a previous study (Rahman \& Tawatao 2003). According to Keng and Rahman (2012), the availability of food resources (i.e. small fronds and dead woods) affected termite assemblages in oil palm plantation.

From the dendrogram generated, the termite assemblages of the shallow and deep peat soils were the same but totally dissimilar to those in the clay soil. Wood feeders are generally the most dominant termite species in peatland converted oil palm plantation due to large amounts of wood debris from logging activity. These termites feed on living and dead wood, including wood litter, dead branches, and fungus attacked wood (Rahman \& Tawatao 2003). The methodology (census method) used in the present study may explain the higher numbers of wood feeders collected in the present study.

\section{CONCLUSION}

We identified 29 species in Endau Rompin Plantation, most of which were wood feeders. These wood feeders were mostly arboreal or subterranean nesters. The results show that termites' feeding and nesting behaviours, which are determined by preferred organic content and moisture levels, respectively, seemed to affect the presence and distribution patterns of the termites in the different types of soil. In this study, both the community structure of the shallow and deep peat soil was the same, suggesting that peat soils have similar environmental conditions for wood feeders with different nesting behaviors. Studies of termite distribution patterns in clay and peat soil are needed to aid understanding of their behaviour and the environmental factors affecting their distribution. In addition, such studies could shed light on the resource utilization behaviour of termites under different environmental condition.

\section{ACKNOWLEDGEMENTS}

The authors would like to thank the management of Yayasan Pahang Plantation Holdings Sdn. Bhd. for the sampling permission. We would like to express our special gratitude to Mrs. Noor Ain Sha'ari, Ms. Fatin Elina Kamarulzaman, Mrs. Shafuraa Onn, Mr. Wan Mohamad Zakhir, Ms. Zeti Aktar Ayub, Ms. Nur Athirah Abdullah, Mrs. Nurul Aina Adnan, Mrs. Juhaida Harun and Ms. Nurul Jannah Abdul Majid for helping in the samplings. The project was supported by GUP-2016-022 and GUP2012-072.

\section{REFERENCES}

Bong, J.C.F., King, P.J.H., Ong, K.H. \& Mahadi, N.M. 2012. Termites assemblages in oil palm plantation in Sarawak, Malaysia. J. Entomol.9(2): 68-78.

Bourguignon, T., Maurice, L. \& Yves, R. 2011. Beta-diversity of termite assemblages among primary french guiana rain forests. Biotropica 43(4): 473-479.

Dawes, T.Z. 2010. Impacts of habitat disturbance on termites and soil water storage in a tropical Australian savanna. Pedobiologia 53(4): 241-246.

De Souza, O.F.F. \& Brown, V.K. 1994. Effects of habitat fragmentation on Amazonian termite communities. J. Trop. Ecol. 10(02): 197-206.

Dibog, L., Eggleton, P., Norgrove, L., Bignell, D.E. \& Hauser, S. 1999. Impacts of canopy cover on soil termite assemblages in an agrisilvicultural sysytem in Southern Cameroon. Bull. Entomol.Res. 89: 125-132.

Donovan, S.E., Griffiths, G.J.K., Homathevi, R. \& Winder, L. 2007. The spatial pattern of soil-dwelling termites in primary and logged forest in Sabah, Malaysia. Ecol.Entomol.32(1): $1-10$.

Donovan, S.E., Eggleton, P. \& Bignell, D.E. 2001. Gut content analysis and a new feeding group classification of termites. Ecol. Entomol. 26(4): 356-366.

Eggleton, P., Homathevi, R., Jones, D.T., MacDonald, J.A., Jeeva, D., Bignell, D.E., Davies, R.G \& Maryati, M. 1999. Termite assemblages, forest disturbance and greenhouse gas fluxes in Sabah, East Malaysia. Philosophical Transactions of the Royal Society of London B: Biological Sciences 354(1391): 1791-1802.

Evans, T.A., Dawes, T.Z., Ward, P.R. \& Lo, N. 2011. Ants and termites increase crop yield in a dry climate. Nat. Commun. 2: 262 .

FAO. 2010. Food and Agriculture Organization of the United Nations. FAOSTAT Online Statistical Service.

Foster, W.A., Snaddon J.L., Turner, E.C., Fayle, T.M., Cockerill, T.D., Ellwood, M.D., Broad, G.R., Chung, A.Y.C., Eggleton, P., Khen, C.V. \& Yusah, K.M. 2011. Establishing the evidence base for maintaining biodiversity and ecosystem function in the oil palm landscapes of South East Asia. Philosophical Transactions of the Royal Society B: Biological Sciences 366(1582): 3277-3291.

Fox-Dobbs, K., Doak, D.F., Brody, A.K. \& Palmer, T.M. 2010. Termites create spatial structure and govern ecosystem function by affecting N2 fixation in an East African savanna. Ecol. 91(5): 1296-1307.

Hanis J.A., Abu Hassan, A., Nurita, A.T. \& Che Salmah. M.R. 2014. Community structure of termites in a hill dipterocarp forest of Belum-Temengor Forest Complex, Malaysia: Emergence of pest species. Raffles B. Zool. 62: 3-11. 
Harris, W.V. 1969. Termites as Pests of Crops and Trees, Termites as Pests of Crops and Trees. London, UK: Commonwealth Institute of Entomology. p. 41.

Hassall, M., Jones, D.T., Taiti, S., Latipi, Z., Sutton, S.L. \& Mohammed, M. 2006. Biodiversity and abundance of terrestrial isopods along a gradient of disturbance in Sabah, East Malaysia. European Journal of Soil Biology 42: S197-S207.

Hemachandra, I.I., Edirisinghe, J.P., Karunaratne, W.A.I.P. \& Gunatilleke, C.V.S. 2010. Distinctiveness of termite assemblages in two fragmented forest types in Hantane hills in the Kandy District of Sri Lanka. Ceylon J. Sci. (Biol Sci) 39(1): 11-19.

Jones, D.T. \& Eggleton, P. 2000. Sampling termite assemblages in tropical forests: Testing a rapid biodiversity assessment protocol. J. Appl. Ecol.37(1): 191-203.

Jones, D.T., Susilo, F.X., Bignell, D.E., Hardiwinoto, S., Gillison, A.N.\& Eggleton, P. 2003. Termite assemblage collapse along a land-use intensification gradient in lowland central Sumatra, Indonesia. J. Appl. Ecol. 40(2): 380-391.

Jouquet, P., Tessier, D. \& Lepage, M. 2004. The soil structural stability of termite nests: Role of clays in Macrotermes bellicosus (Isoptera, Macrotermitinae) mound soils. Eur. J. Soil. Biol. 40(1): 23-29.

Jouquet, P., Traoré, S., Choosai, C., Hartmann, C. \& Bignell, D. 2011. Influence of termites on ecosystem functioning. Ecosystem services provided by termites. European Journal of Soil Biology 47(4): 215-222.

Keng, W.M. \& Rahman, H. 2012. Logistic regression to predict termite occurrences with environmental variables in primary forest and oil palm ecosystem: The case study in Sabah, Malaysia. APCBEE Procedia 4: 53-57.

Kirton, L.G. \& Wong, A.H.H. 2001. The economic importance and control of termite infestations in relation to plantation forestry and wood preservation in Peninsular Malaysia-an overview. Sociobiol. 37(2): 325-349.

Kon, T.W., Bong, C.F.J., King, J.H.P. \& Leong, C.T.S. 2012. Biodiversity of termite (Insecta: Isoptera) in tropical peat land cultivated with oil palms. Pak. J. Biol. Sci. 15(3): 108-120.

Lee, C.Y. 2002. Subterrenean termite pests and their control in the urban environment in Malaysia. Sociobiology 40: 3-9.

Lim, K.H. \& Silek, B. 2001. Termite infestation on oil palms planted on deep peat in Sarawak: Tradewinds experience. Paper read at Proceedings 2001 International Palm Oil Congress (PIPOC) at Kuala Lumpur.

Luke, S.H., Fayle, T.M., Eggleton, P., Turner., E.C. \& Davies, R.G. 2014. Functional structure of ant and termite assemblages in old growth forest, logged forest and oil palm plantation in Malaysian Borneo. Biodivers. Conserv. 23(11): 2817-2832.
McCune, B. \& Mefford, M.J. 2011. PC-ORD v. 6.255 beta. MjM Software. Gleneden Beach, Lincoln.

Omar, W., Aziz, N.A., Mohammed, A.T., Harun, M.H. \& Din, A.K. 2010. Mapping of oil palm cultivation on peatland in Malaysia. MPOB Informafion Series.

Rahman, H. \& Tawatao, N. 2003. Isoptera (Termite) (Adapted from Inventory and collection, 2003).

Syaukani. 2010. A Guide to the Nasus Termites (Nasutitermitinae, Termitidae) of Kerinci Seblat National Park Sumatra. Kagoshima, Japan: Nagao Natural Environment Foundation.

Thapa, R.S. 1981. Termites of Sabah. Vol. 12: Sabah Forest Records.

Tho, Y.P. 1992. Termites of Peninsular Malaysia. Vol. 36: Malaysia Forest Records.

Turner, E.C., Snaddon, J.L., Ewers, R.M., Fayle, T.M. \& Foster, W.A. 2011. The impact of oil palm expansion on environmental change: Putting conservation research in context InTech. doi: 10.5772/20263

Vaessen, T., Verwer, C., Demies, M., Kaliang, H. \& Van Der Meer, P.J. 2011. Comparison of termite assemblages along a landuse gradient on peat areas in Sarawak, Malaysia. J.Trop. For. Sci. 23: 196-203.

Nur-Atiqah Jalaludin \& Salmah Yaakop*

School of Environmental and Natural Resources Sciences

Faculty of Science and Technology

Universiti Kebangsaan Malaysia

43600 UKM Bangi, Selangor Darul Ehsan

Malaysia

Faszly Rahim

Permata Insan College

Universiti Sains Islam Malaysia

PERMATA Insan Complex, Bandar Baru Nilai

71800, Nilai, Negeri Sembilan Darul Khusus

Malaysia

*Corresponding author; email: salmah78@ukm.edu.my

Received: 14 September 2017

Accepted: 23 May 2018 